\title{
THE DETERMINANTS OF STOCK PRICE VOLATILITY IN INDONESIA
}

\author{
Bambang Sutrisno \\ Universitas Muhammadiyah Jakarta, Tangerang Selatan, Indonesia \\ bsutrisno.umj@gmail.com
}

\begin{abstract}
Volatility reflects stock price fluctuation in a certain period. The objective of this research is to examine the effect of trading volume, firm size, inflation, and exchange rate on stock volatility of the Jakarta Islamic Index companies from 2014 to 2018. By using a purposive sampling technique, the research sample is sixteen companies. This research employs panel regression with annual data. This study reveals that the stock trading volume significantly affects stock price volatility. Firm size is negatively related to price volatility. Meanwhile, the inflation and exchange rate do not affect stock volatility.
\end{abstract}

Keywords: stock price volatility; trading volume; firm size; inflation; exchange rate

\section{INTRODUCTION}

Volatility means the price fluctuation of security or commodity for a specified period. Volatility is identical to risk. The higher the volatility, the higher the uncertainty of the return. If the daily volatility is very high, it gives space to make trades or transactions to benefit from the difference from the initial price with the final price (margin) at the time of the transaction; however, the risk is also huge. Meanwhile, stock price with low volatility means the stock price movements are shallow. In this condition, investors usually cannot get profit, but they must hold shares in the long run to obtain profit (capital gain). Therefore, investors who like to do trading strategies are very fond of high volatility, but longterm investors are very fond of low volatility, but share prices increases (Chan and Fong, 2000).
Macro and micro factors can influence high and low stock price volatility. Macro factors are factors that affect the overall economy, including interest rate, exchange rate, inflation, money supply, oil prices, and other factors that have an essential impact on companies. On the other hand, micro factors are factors that have a direct impact on the company itself, such as management change, price, availability of raw materials, and other factors that can affect the profit performance of individual companies, including funding. However, from these factors, it is difficult to determine which factors have the most dominant influence on stock price volatility (Romli et al., 2017).

The objective of this study is to examine the impact of macro and micro factors on the stock price volatility. This research is essential 
for the company to pay attention to factors that can affect the volatility of the company's stock price so that the firm can maintain share performance. This study is also beneficial to the investors in investment decision making to see what factors can affect the volatility of the stock price.

\section{LITERATURE REVIEW}

\subsection{Trading Volume}

Trading volume is a vital aspect for an investor because it reflects the condition of shares traded on the capital market affect the stock price. Dewi and Suaryana (2016) state that if there is no information about stocks, investors are more likely to keep holding their shares. Trading volume will decrease because not many shares are sold, then it will result in low volatility. Vice versa, if investors receive a lot of information about a stock, then investors will sell their shares a lot, this will result in increased trading volume of shares. As a result of the increase in trading volume, the volatility also rises. Chan and Fong (2000) found that trading volume influences volatility because the volume reflects the information received by market participants.

$\mathrm{H}_{1}$ : Trading volume affects stock price volatility.

\subsection{Firm Size}

Small company shares are more liquid than a large company, causing the stock price to be more volatile. Hashemijoo et al. (2012) find that company size significantly affects stock volatility. The bigger the firm size, the higher the diversification of activities so that large companies usually have more public information and can reduce the level of price volatility. Nasir et al. (2018) find similar findings to Hashemijoo et al. (2012).

$\mathrm{H}_{2}$ : Company size affects stock volatility.

\subsection{Inflation}

The higher the money supply will lead to a higher discount rate and lower stock prices. An increase in the inflation rate will lead to tighter economic policies and will hurt stock prices. Hugida (2011) proves that inflation affects stock price volatility. The negative impact will encourage investors to sell shares owned so that it will result in increased volatility in stock prices.

$\mathrm{H}_{3}$ : Inflation affects stock price volatility.

\subsection{Exchange Rate}

The exchange rate is the amount of rupiah needed to get one unit of foreign currency. The exchange rate is one indicator that influences the capital market and money market activities. Yogaswari (2012) states that the exchange rate affects price volatility. If the dollar strengthens and the rupiah weakens, then it is likely that investors will tend to shift their investment in US dollars in foreign currency compared to investing in stocks and vice versa.

$\mathrm{H}_{4}$ : The exchange rate affects stock price volatility.

\section{RESEARCH METHOD}

This study is explanatory research. It is useful for examining 
the impact of independent variables on the dependent variable.

\subsection{Data Collection Techniques}

This research uses secondary data from www.finance.yahoo.com, www.idx.co.id, www.bps.go.id, and www.bi.go.id.

\subsection{Operational Definitions of Variables}

The dependent variable of this research is stock price volatility. This study applies four independent variables, namely trading volume, firm size, inflation, and exchange rate. The calculation of each research variable is explained as follows.

I employ range-based volatility to calculate stock price volatility (Sutrisno, 2017).

$\sigma=\sqrt{\frac{1}{n} \sum \operatorname{Ln}\left(\frac{H t}{L t}\right)^{2}}$

$\sigma$ is stock price volatility, Ht is the highest price, Lt is the lowest price, and $\mathrm{n}$ is the number of days in a year.

The computation of trading volume uses the following formula.

$$
T V A=\frac{\text { Number of shares traded }}{\text { Shares outstanding }}
$$

Firm size is calculated by using the following formula.

Size $=$ Ln (Total Assets)

The inflation rate is computed by using this formula.

$$
C P I=\frac{C P I_{t}-C P I_{t-1}}{C P I_{t-1}}
$$

$\mathrm{CPI}$ is consumer perception index.

The formula of the exchange rate is as follows.

Middle rate

$$
=\frac{\text { Offer rate }+ \text { Bid rate }}{2}
$$

\subsection{Sample Collection Techniques}

This study uses a purposive sampling technique to determine the research sample. The criteria for the sample selection process are as follows: (1) the companies are consistently included in the Jakarta Islamic Index from 2014 to 2018, and (2) the companies have complete data. The final sample is sixteen firms for the last five years. This study has eighty observations.

\subsection{Data Analysis Techniques}

This study employs panel regression to hypotheses testing. First, this study displays the summary statistics of each variable. Second, the study determines the best estimation method. The next step is the classical assumption tests. The last stage is hypotheses testing using probability value. The level of significance in this study is $5 \%$. This study uses EViews 10 to process the research data.

\section{RESULTS DISCUSSION}

AND

\section{Descriptive Statistics}

Table 1 displays the summary statistics of each variable. The average stock price volatility is $3.06 \%$. Meanwhile, the average trading volume is $30.90 \%$. Firm size, inflation, and exchange rate have mean values of $18.10,5.34 \%$, and 9.48 , respectively.

Table 1: Descriptive Statistics

\begin{tabular}{|lccccc|}
\hline & $\begin{array}{c}\text { Me } \\
\text { Variable }\end{array}$ & $\begin{array}{c}\text { Me } \\
\text { dian }\end{array}$ & Min & $\begin{array}{c}\text { Ma } \\
\text { x }\end{array}$ & $\begin{array}{c}\text { Std. } \\
\text { Dev. }\end{array}$ \\
\hline Volatilit & 0.03 & 0.03 & 0.05 & 0.01 & 0.00 \\
y & 06 & 05 & 37 & 75 & 82 \\
Trading & 0.30 & 0.29 & 0.91 & 0.02 & 0.15 \\
\hline
\end{tabular}




\begin{tabular}{|lccccc|}
\hline Volume & 90 & 56 & 53 & 98 & 06 \\
Firm & 18.0 & 18.0 & 20.8 & 16.0 & 1.15 \\
Size & 957 & 899 & 422 & 789 & 66 \\
& 0.05 & 0.03 & 0.08 & 0.03 & 0.02 \\
Inflation & 34 & 61 & 38 & 02 & 49 \\
Exchang & 9.47 & 9.50 & 9.53 & 9.40 & 0.04 \\
e Rate & 53 & 19 & 21 & 83 & 83 \\
\hline
\end{tabular}

\section{Determining the Best Estimation Method}

This research employs the Chow test, Hausman test, and Lagrange Multiplier test (LM test) to choose the best estimation method (Ekananda, 2016). The results of the Chow test, Hausman test, and LM test are summarized in Table 2. Chow test reveals that the best estimation method to choose is the fixed effect. The Hausman test states that random effect is the best estimation method to determine. LM test explains that random effect is chosen as the best estimation method. Therefore, the random effect is used to estimate panel data.

Table 2: Determination of the Best Estimation Model

\begin{tabular}{|l|c|c|}
\hline Chow Test & Prob. & Conclusion \\
\hline $\begin{array}{l}\text { Hausman } \\
\text { Test }\end{array}$ & 1.0000 & $\begin{array}{c}\text { Fixed Effect } \\
\text { Model }\end{array}$ \\
\hline LM Test & 0.0298 & $\begin{array}{c}\text { Random Effect } \\
\text { Model }\end{array}$ \\
\hline
\end{tabular}

\section{Classical Assumption Tests}

This study does not use the classical assumption tests because the best estimation method chosen is the random effect model. According to Gujarati and Porter (2010), equations that meet classical assumption tests are only equations that employ the generalized least square (GLS) method. In EViews, the estimation model that uses the GLS method is an only random effect; meanwhile, the fixed effect and common effect employ ordinary least square (OLS).

\section{Hypotheses Testing}

Table 3 summarizes the result of panel regression. The regression equation is as follows.

VOLAT $=0.222466$

$$
\begin{aligned}
& +0.011344 \text { VOLUME } \\
& -0.002834 \text { SIZE } \\
& +0.024566 \text { INF } \\
& -0.015343 \text { KURS }
\end{aligned}
$$

The results of the probability value of each independent variable can be described as follows:

1) Trading volume has a significant positive effect on price volatility because the coefficient is positive, and its probability value is less than $5 \%$. Thus, hypothesis one is accepted.

2) Firm size has a significant negative effect on stock price volatility because the coefficient is negative, and its probability value is smaller than 5\%. Hypothesis two is accepted.

3) Inflation does not influence stock volatility because its probability value is more than 5\%. Therefore, hypothesis three is rejected.

4) The exchange rate does not have an impact on price volatility because its probability value is bigger than 5\%. Thus, hypothesis four is rejected.

The coefficient of determination (R-squared) of this study is $16.35 \%$. It means that trading volume, firm 
size, inflation, and exchange rate can explain stock price volatility of $16.35 \%$, while the rest $(83.65 \%)$ is explained by other variables not included in the research model.

Table 3: The Result of Panel Regression

\begin{tabular}{|l|c|c|}
\hline \multicolumn{1}{|c|}{ Variable } & Coefficient & Prob. \\
\hline Constanta & 0.222466 & 0.6397 \\
\hline Trading Volume & 0.011344 & 0.0297 \\
\hline Firm Size & -0.002834 & 0.0024 \\
\hline Inflation & 0.024566 & 0.7992 \\
\hline Exchange Rate & -0.015343 & 0.7570 \\
\hline R-squared & 0.163548 & \\
\hline
\end{tabular}

\section{Discussion}

The Effect of Trading Volume on Stock Price Volatility

This study finds that trading volume positively and significantly affects stock volatility. The higher the trading volume, the higher the stock volatility. This finding is in line with Chan and Fong (2000), Hugida (2011), Dewi and Suaryana (2016), Romli et al. (2017), and Nasir et al. (2018). The small trading volume indicates that investors are not interested in investing. On the reverse, the large trading volume shows that many investors are interested in making transactions to buy and sell shares so that stock prices are more volatile.

\section{The Effect of Firm Size on Stock Price Volatility}

This study shows that company size negatively affects stock price volatility. The smaller the firm size, the higher the volatility. This result is similar to Anastassia and Firnanti (2014) and Nasir et al. (2018). Small stocks are more volatile than big stocks, so that their stock price fluctuates. A large amount of company assets does not necessarily have a positive relationship with the volatility of the company's stock prices. The larger the firm size, the higher the diversification of activities. This condition can reduce the volatility level.

\section{The Effect of Inflation on Stock Price Volatility}

Inflation has no significant impact on price volatility. This study supports Yogaswari et al. (2012) and Romli et al. (2017). Investors who want to invest in JII stocks need not consider the inflation rate as long as the inflation rate is under $10 \%$. Investors assume that investing in JII stocks will continue to generate profit because JII stocks are Islamic stocks with high liquidity.

\section{The Effect of Exchange Rate on Stock Price Volatility}

The exchange rate does not affect stock volatility. This result is not similar to Amin and Herawati (2012). They find that the exchange rate significantly and negatively affects stock volatility. This different result can be caused by the difference in the research sample and period. The insignificant exchange rate informs that strengthening or weakening the exchange rate does not have an impact on stock volatility. If the rupiah and dollar 
strengthen, then investors tend to divert their investment in the form of shares compared to investing in foreign exchange.

\section{CONCLUSION}

This study concludes that trading volume shows a significant positive effect on stock price volatility. Firm size negatively affects stock volatility. On the other hand, inflation and the exchange rate have no relationship with price volatility.

This study implies that the companies included in JII from 2014

\section{REFERENCES}

Amin, M. Z., \& Herawati, T. D. (2012). Pengaruh tingkat inflasi, suku bunga SBI, nilai kurs dolar (USD/IDR), dan Indeks Dow Jones (DJIA) terhadap pergerakan Indeks Harga Saham Gabungan di Bursa Efek Indonesia (BEI) (Periode 2008-2011).

Malang: Fakultas Ekonomi dan Bisnis Universitas Brawijaya.

Anastassia, \& Firnanti, F. (2014). Faktor-faktor yang mempengaruhi volatilitas harga saham pada perusahaan publik nonkeuangan. Jurnal Bisnis dan Akuntansi, 16(2), 95-102.

Chan, K., \& Fong, W. (2000). Trade size, order imbalance, and the volatility-volume relation. Journal of Financial Economics, 57(2), 247-273. zto 2018 should pay more attention to internal factors, especially in trading volume and firm size, so that they can maintain their share performance. The investors should consider the trading volume and firm size in their investment decision. This study has two recommendations for future studies. First, further studies can use another proxy for price volatility, such as squared returns. Second, future research can use other factors that affect stock price volatility.

Dewi, N. M., \& Suaryana, I. G. (2016). Pengaruh volume perdagangan saham, leverage, dan tingkat suku bunga terhadap volatilitas harga saham. E-Jurnal Akuntansi Universitas Udayana, 17(2), 1112-1140.

Ekananda, M. (2016). Analisis Ekonometrika Data Panel Edisi 2. Bogor: Mitra Wacana Media.

Gujarati, D. N., \& Porter, D. C. (2010). Dasar-dasar Ekonometrika. Jakarta: Salemba Empat.

Hashemijoo, M., Ardekani, A. M., \& Younesi, M. (2012). The impact of dividend policy on share price volatility in the Malaysian stock market. Journal of Business Studies Quarterly, 4(1), 111-129. 
EAJ (Economics and Accounting Journal) - Vol. 3, No. 1, Jan 2020 - Sutrisno

Hugida, L. (2011). Analisis faktorfaktor yang mempengaruhi volatilitas harga saham (Studi pada perusahaan yang terdaftar dalam indeks LQ45 periode 2006-2009. Semarang: Fakultas Ekonomi Universitas Diponegoro.

Nasir, J. L., Diana, N., \& Mawardhi, M. C. (2018). Analisis faktorfaktor yang mempengaruhi volatilitas harga saham. EJRA, 7(9), 24-38.

Romli, H., Wulandari, M. F., \& Pratiwi, T. S. (2017). Faktorfaktor yang mempengaruhi volatilitas harga saham pada PT Waskita Karya Tbk.
Jurnal Ilmiah Ekonomi Global Masa Kini, 8(1), 1-5.

Sutrisno, B. (2017). Hubungan volatilitas dan volume perdagangan di Bursa Efek Indonesia. Esensi: Jurnal Bisnis dan Manajemen, 7(1), 15-26.

Yogaswari, D. D., Nugroho, A. B., \& Astuti, N. C. (2012). The effect of macroeconomic variables on stock price volatility: Evidence from Jakarta Composite Index, agriculture, and basic industry sector. International Proceedings of Economics Development Research, 46, pp. 96-100. 